\title{
Photoeletrocatalytic Oxidation of Anionic Surfactant used in Leather Industry on Nanoporous $\mathrm{Ti} / \mathrm{TiO}_{2}$ Eletrodes
}

\author{
Fabiana M. M. Paschoal, ${ }^{a}$ Marc A. Anderson ${ }^{b}$ and M. Valnice B. Zanoni ${ }^{*, a}$ \\ ${ }^{a}$ Departamento de Química Analítica, Instituto de Química, Universidade Estadual Paulista, \\ Av. Prof. Francisco Degni, s/n, CP 355, 14801-970 Araraquara-SP, Brazil \\ ${ }^{b}$ Environmental Chemistry and Technology Program, University of Wisconsin-Madison, 660 N. Park Street, \\ Madison, WI 53706, USA
}

\begin{abstract}
A oxidação fotoeletrocatalítica de solução $0,009 \%(\mathrm{~m} / \mathrm{v})$ do surfactante aniônico comercial, $\mathrm{Tamol}^{\circledR}$, foi investigada em $\mathrm{Na}_{2} \mathrm{SO}_{4} 0,1 \mathrm{~mol} \mathrm{~L}^{-1}$ empregando-se ânodos de filme fino de Ti/TiO, Utilizando-se as melhores condições experimentais, potencial de $+1,0 \mathrm{~V}$, irradiação UV e pH 2,0 foi possível obter $100 \%$ de remoção do dispersante monitorado por espectrofotometria na região do UV e 94\% de remoção de carbono orgânico total (COT) após 90 min de fotoeletrólise. O método foi ainda aplicado para remoção do surfactante na presença do corante acido vermelho 151 e após 90 min de tratamento observa-se que o método promove a remoção de $98 \%$ da cor concomitante à diminuição de $81 \%$ do carbono orgânico total da solução.
\end{abstract}

The photoeletrocatalytic oxidation of $0.009 \%(\mathrm{~m} / \mathrm{v})$ of commercial surfactant Tamol $^{\circledR}$ in $0.1 \mathrm{~mol} \mathrm{~L}^{-1} \mathrm{Na}_{2} \mathrm{SO}_{4}$ was investigated on thin-film of $\mathrm{TiO}_{2}$ as photoanode. Using the best experimental condition, $\mathrm{E}=+1.0 \mathrm{~V}, \mathrm{pH} 2.0$ and $\mathrm{UV}$ irradiation were obtained $100 \%$ of surfactant removal followed by $94 \%$ of total organic carbon (TOC) removal after 90 min of photoelectrocatalytic treatment. The method was applied to surfactant removal in the presence of acid red 151 dye. After 90 min of treatment the method promoted $98 \%$ of discoloration concomitant to reduction of $81 \%$ total organic carbon of the resulting solution.

Keywords: surfactant oxidation, photoelectrocatalysis, photoelectrochemistry, thin-film electrodes, $\mathrm{Ti} / \mathrm{TiO}_{2}$

\section{Introduction}

As dyes solubilization in surfactant micelles plays an important role in dyeing process, residual surfactants and their degradation products discharged to sewage treatment plants or directly to surface waters are object of concern. ${ }^{1,2}$

Dyeing of leather is one of the most important steps in post tanning operations in leather production, in which anionic surfactant is used to stabilize the color and also to improve the fixation onto the three-dimensional structure of the fiber involved in leather..$^{1-3}$ According to the literature, ${ }^{3}$ both anionic and nonionic surfactants at concentrations ranging from 0.0025 to $300 \mathrm{mg} \mathrm{L}^{-1}$, give toxic effects to various aquatic ecosystem. Tamol ${ }^{\circledR}$ is a commercial anionic surfactant based on naphtelene sulphonic being frequently

\footnotetext{
*e-mail: boldrinv@iq.unesp.br
}

used in the leather dyeing stage. The growing use of this kind of surfactant is in disagreement with the scarce of treatment methods present in the literature to remove them from surface water. ${ }^{4-19}$

Many water treatment methods based on removal of organic polluting agents are in many cases expensive and inefficient. Therefore, new methods and technologies of water treatment have being explored with the aim to reach complete mineralization of contaminants. Studies on photodegradation of surfactants with the use of heterogeneous photocatalysis with $\mathrm{TiO}_{2}$ as substrate have shown efficient degradation. ${ }^{4-12}$ Electrochemistry coagulation method was also investigated and presented good results. ${ }^{13}$ Lin et al. ${ }^{14}$ have investigated the application of Fenton reagent to treat anionic surfactant. Due to the nature of the surfactant, the surfactant biodegradation process have demonstrated degradation around only $20 \% .{ }^{15}$ The results are improved by 
coupling biodegradation process with photochemical treatment ${ }^{15}$ that reach $74 \%$ of surfactant removal and with ozonization ${ }^{16}$ that increase the removal efficiency of the surfactant to $50 \%$. The application of photoelectrochemistry to study degradation of sodium dodecylbenzenesulfonate surfactant has been published by Hidaka et al. ${ }^{17}$ The method is based on oxidation on $\mathrm{TiO}_{2} / \mathrm{SnO}_{2}$ thin-film electrode and the results point to $89 \%$ of surfactant removal after $4 \mathrm{~h}$ of photodegradation.

The present study aimed at investigating the degradation of a commercial anionic surfactant being frequently used in leather industry by photoelectrocatalytic oxidation on $\mathrm{Ti} / \mathrm{TiO}_{2}$ anodes. Nanostructured semiconductor $\mathrm{Ti} / \mathrm{TiO}_{2}$ thin-film electrodes have been extensively studied. ${ }^{20,21}$ Titanium dioxide itself has been prepared by the sol-gel chemistry method and coated on a different supports to produce thin-film photoelectrodes as reported previously. ${ }^{22,23}$ Besides the electrochemical stability, these new electrodes have large internal surface areas, which contribute to higher efficiency for decontaminating organic pollutants. ${ }^{24-27}$

In the present work, the feasibility of photoelectrochemical oxidation of a commercial anionic surfactant, $\mathrm{Tamol}^{\circledR}$, in sodium sulphate solution using titanium dioxide thin-film electrodes prepared by the sol-gel method was investigated. The effects of azo dye on the degradation rate of this surfactant were evaluated. Photoelectrocatalytic methods are then optimized to situations close to that occurring in textile effluent.

\section{Experimental}

\section{Preparation of $\mathrm{Ti} / \mathrm{TiO}_{2}$ thin-film electrodes}

Titanium (IV) isopropoxide (Aldrich) was used as a precursor for preparing $\mathrm{TiO}_{2}$ colloidal suspensions. Typically, $20 \mathrm{~mL}$ of titanium isoporpoxide were added to a nitric acid solution keeping the ratio $\mathrm{Ti} / \mathrm{H}^{+} / \mathrm{H}_{2} \mathrm{O}$ at $1 / 1.5 / 200$. The resulting precipitate was continuously stirred until completely peptized to a stable colloidal suspension. This suspension was dialyzed against ultrapure water (Milli-Q Millipore) to a $\mathrm{pH}$ of 3.5 with a Micropore $3500 \mathrm{MW}$ cut off membrane. Thin-film photoelectrodes were dip-coated onto a titanium foil back contact ( 0.05 or $0.5 \mathrm{~mm}$ thick, Goodfellow Cambridge Ltd.), after heating the Ti foils to $350{ }^{\circ} \mathrm{C}$. A sequence of dipping, drying and firing at $350{ }^{\circ} \mathrm{C}$ for $3 \mathrm{~h}$ were used after each coating (five repetitions), according a procedure described earlier. ${ }^{20,22,23,27}$

\section{Apparatus and procedure}

Photoelectrocatalytic oxidation experiments were performed in a $250 \mathrm{~mL}$ reactor (Figure 1) equipped with water refrigeration using an ultra-thermostatic bath (Nova Técnica, Brazil) at constant temperature of $25^{\circ} \mathrm{C}$. In the cell, was positioned a working electrode, an auxiliary electrode and $\mathrm{a} \mathrm{Ag} / \mathrm{AgCl}$ electrode placed close to the working electrode using a bridge tube containing a Vycor frit tip. The photoactive area of the anode $\left(\mathrm{TiO}_{2}\right)$ was $12 \mathrm{~cm}^{2}$ and it was illuminated by a UV light source (315-400 nm) from a 125 W Philips medium pressure mercury lamp $\left(I=9.23 \mathrm{~W} / \mathrm{m}^{2}\right)$ without the glass, inserted in a quartz bulb separated $2.5 \mathrm{~cm}$ from the photoanode. Surfactant and dye in $0.1 \mathrm{~mol} \mathrm{~L}^{-1}$ $\mathrm{Na}_{2} \mathrm{SO}_{4}$ solutions were placed in the reactor without any pre treatment and the photoelectrochemical process was carried out bubbling compressed air. A Pt gauze electrode was used as counter electrode.

A potentiostat/galvanostat EG \& G PARC Model 283 controlled by an electrochemical 270 software was used to bias the photoanode in the photoelectrocatalytic oxidation experiments. All $\mathrm{pH}$ measures of $\mathrm{Tamol}^{\circledR}$ and acid red 151 dye solutions in $0.1 \mathrm{~mol} \mathrm{~L}^{-1} \mathrm{Na}_{2} \mathrm{SO}_{4}$ were made by $\mathrm{pHmeter}$ Corning 555. In experiments where $\mathrm{pH}$ was kept constant, $0.1 \mathrm{~mol} \mathrm{~L}^{-1} \mathrm{NaOH}$ solution or $\mathrm{H}_{2} \mathrm{SO}_{4}$ solution was added to the cell in order to control the $\mathrm{pH}$.

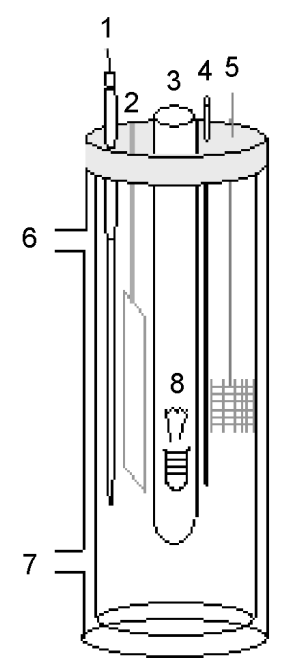

Figure 1. Schematic diagram of the photoelectrochemical reactor constructed in glass water refrigerated by an ultra-thermostatic bath containing: (1) reference electrode; (2) working electrode; (3) quartz bulb; (4) air; (5) counter electrode; (6) and (7) water circulation; (8) Lamp of $125 \mathrm{~W}$ Philips medium pressure mercury without the glass.

Surfactant Tamol ${ }^{\circledast}$ concentration and acid red 151 in the solution were monitored by measuring the surfactant samples absorbance and dye solutions at controlled time using a Hewlett Packard 8453 spectrophotometer operating 
from 190-1,000 nm in quartz cell. Total organic carbon (TOC) was monitored using a total organic carbon analyzer (Shimadzu 5000A).

\section{Chromatographic conditions}

A high performance liquid chromatograph Shimadzu Model 10 AVP coupled with a photodiode array detector was used to separate and identify products and intermediates of the surfactant oxidation. The separation column was C-18 $(4.6 \mathrm{~mm} \times 250 \mathrm{~mm}, 5 \mu \mathrm{m})$ and the mobile phase was acetonitrile:water (80:20) flowing at $1.0 \mathrm{~mL} \mathrm{~min}{ }^{-1}$. Signals obtained from detector were analyzed by area integration.

Standard curves and quantitative analysis of standard Tamol ${ }^{\circledR}$ were carried out by linear regression plotting peak area $v s$. concentration. The procedure was carried out in triplicate for each sample.

\section{Results and Discussion}

\section{Characteristics of the photoanode}

The effect of surfactant Tamol ${ }^{\circledR}$ on curves of photocurrent $v s$. potential recorded for oxidation on nanoporous electrode of $\mathrm{Ti} / \mathrm{TiO}_{2}$ in $0.1 \mathrm{~mol} \mathrm{~L}^{-1} \mathrm{Na}_{2} \mathrm{SO}_{4}$ is shown in Figure 2. Typically, the voltammograms recorded at the nanoporous $\mathrm{TiO}_{2}$ film electrode in the dark do not shown any oxidation peak under UV irradiation, but as expected for an n-type semiconductor electrode such as $\mathrm{TiO}_{2}$ produces a high anodic photocurrent at potentials positive $(-0.40 \mathrm{~V})$ to the flat band potential, as shown in curve $b$ of Figure 2. The photocurrent is markedly decreased in the presence of surfactant, as shown in curves c-g, Figure 2. The influence of surfactant concentration on the photocurrent values taken at $\mathrm{E}=+0.4 \mathrm{~V}$, decreases markedly when Tamol ${ }^{\circledR}$ concentration is increased in solution up to $0.010 \%(\mathrm{~m} / \mathrm{v})$, then reaches saturation (Figure 3). Using the data fit to a Langmuir- Hinshelwood ${ }^{28}$ model plotting $1 / \mathrm{Ip}_{\mathrm{hs}}$ vs. $1 / \mathrm{C}$ of $\mathrm{Tamol}^{\circledast},(\mathrm{C}=$ surfactant concentration $(\% \mathrm{~m} / \mathrm{v})$ and $\mathrm{Ip}_{\mathrm{hs}}$ is the photocurrent measured at $\left.\mathrm{E}=+0.4 \mathrm{~V}\right)$, one can observe that in the low concentration region $(<0.015 \% \mathrm{~m} / \mathrm{v})$ a straight line is obtained and agrees well with the model, suggesting that the main mechanism operating here is via adsorption of surfactant molecules onto the electrode surface. So, at higher Tamol ${ }^{\circledR}$ concentration, there is a small constant photocurrent flux, attesting the competitive process responsible for lower efficiency in photogenerated charges separation. Therefore, photoelectrocatalysis could be an efficient alternative only to treat wastewater containing diluted Tamol ${ }^{\circledR}$ solution as $0.009 \%(\mathrm{~m} / \mathrm{v})$, which conditions was adopted in the present work and it is close to that verified for leather industry effluent.

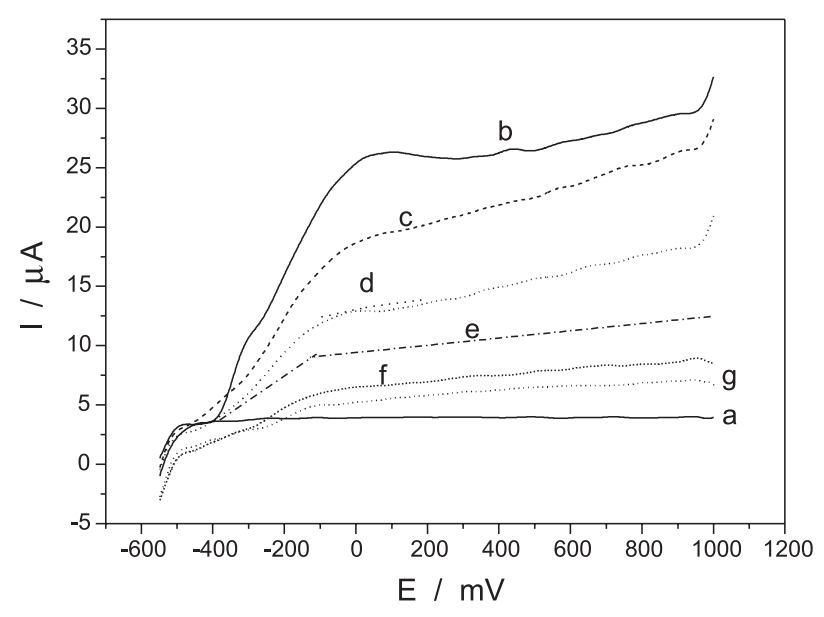

Figure 2. Photocurrent/potential curves obtained for $\mathrm{TiO}_{2}$ thin-film electrode in $0.1 \mathrm{~mol} \mathrm{~L}^{-1} \mathrm{Na}_{2} \mathrm{SO}_{4}$ (Curve b) under UV illumination and in dark conditions (Curve a). Scan rate $=10 \mathrm{mV} \mathrm{s}^{-1}$. Addition of Tamol ${ }^{\circledR}$ surfactant: Curve (c) $0.00075 \%$, Curve (d) $0.0030 \%$, Curve (e ) $0.0075 \%$, Curve (f) $0.015 \%$ and Curve (g) $0.030 \%(\mathrm{~m} / \mathrm{v})$.

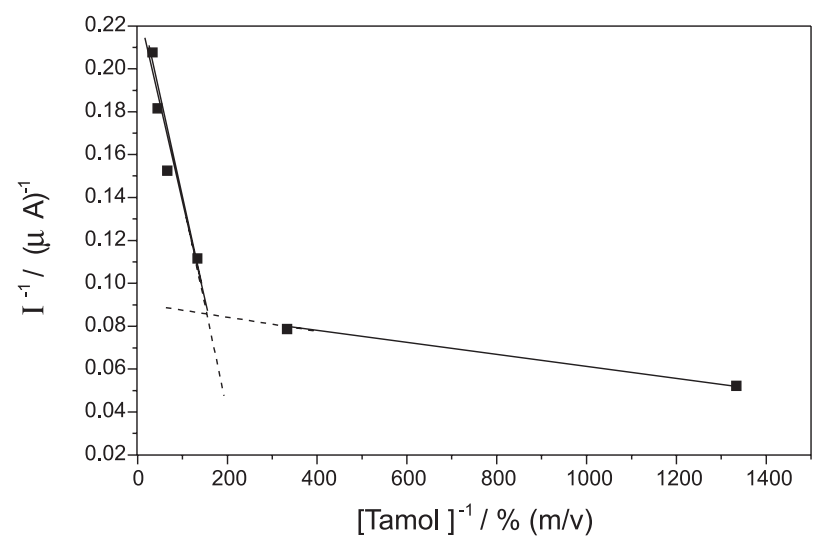

Figure 3. Graphs of $1 / \mathrm{I}_{\mathrm{phs}} v s\left[\mathrm{C}_{\text {surfactant }}\right]^{-1}$ obtained from linear voltammograms

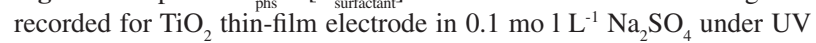
illumination in different concentration of Tamol ${ }^{\circledR}$ surfactant. Scan rate $=10 \mathrm{mV} \mathrm{s}^{-1}$.

\section{Photoelectrocatalytic oxidation of Tamol ${ }^{\circledR}$ surfactant}

As calculated from onset potential measurements, the flat-band potential for $\mathrm{TiO}_{2}$ in $0.1 \mathrm{~mol} \mathrm{~L}^{-1} \mathrm{Na}_{2} \mathrm{SO}_{4}$ media is about $-0.38 \mathrm{~V}$, and optimal performance of photoelectrocatalysis oxidation of surfactants has been obtained at applied potentials around $+1.0 \mathrm{~V}$. At this potential there is always gradient potential over the titanium film, resulting in an electric field, which keeps photogenerated charges $\left(\mathrm{h}^{+}\right.$and $\mathrm{e}^{-}$generated on the electrode surface due irradiation of UV light lower than $380 \mathrm{~nm}$ ) apart. As a result, rate of recombination decreases and oxidation of the adsorbed water on the electrode surface generates powerful oxidants such as $\mathrm{OH}^{\bullet}$ radicals that promote faster dye decomposition and dispersing agent in the solution. In agreement with previous studies, ${ }^{24,29-33}$ all experiments were 
carried out using $+1.0 \mathrm{~V}$ as applied potential were good performance is obtained for $\mathrm{Ti}^{-} \mathrm{TiO}_{2}$ anodes.

UV-Vis spectra obtained before and after the photoelectrocatalytic oxidation of $0.009 \%(\mathrm{~m} / \mathrm{v}) \mathrm{Tamol}^{\circledR}$ surfactant in $0.1 \mathrm{~mol} \mathrm{~L}^{-1}$ solutions of $\mathrm{Na}_{2} \mathrm{SO}_{4}$ on $\mathrm{Ti} / \mathrm{TiO}_{2}$ anodes are exhibited in Figure 4. The surfactant has shown two main bands at $285 \mathrm{~nm}(\mathrm{~A})$ and $224 \mathrm{~nm}$ (B) attributed to the aromatic centre of naphthalene sulphonic derivative of the molecule. But, the photoelectrocatalytic oxidation promotes rapid degradation. This degradation process significantly modifies the chemical structure of surfactant, as shown by the total suppression after 90 min of electrolysis of the absorbance peaks at all UV region. In practice, this species completely disappeared after 120 min of electrolysis.

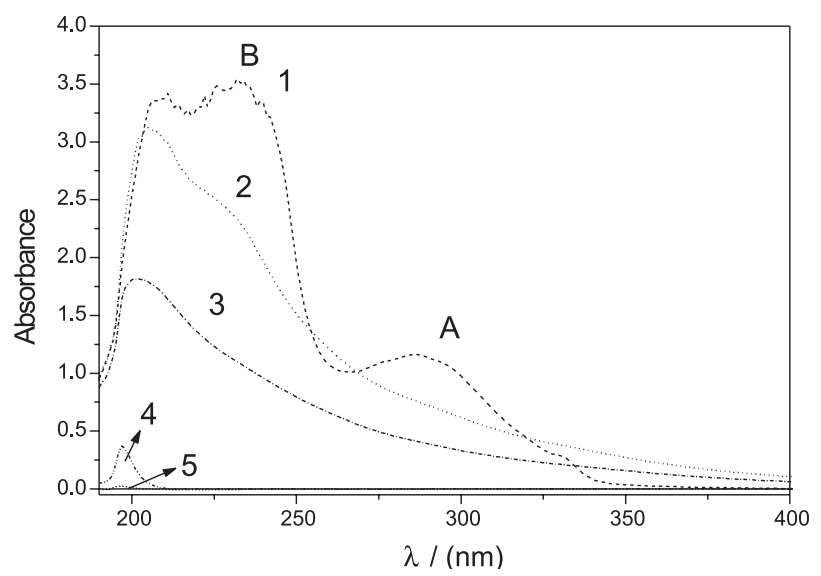

Figure 4. UV spectra obtained for $0.009 \%(\mathrm{~m} / \mathrm{v}) \mathrm{Tamol}^{\circledR}$ in $\mathrm{Na}_{2} \mathrm{SO}_{4}$ $0.1 \mathrm{~mol} \mathrm{~L}^{-1}$ after photoelectrocatalytic oxidation at $+1 \mathrm{~V}$ and $\mathrm{UV}$ irradiation. Time of electrolysis: (1) $0 \mathrm{~min}$; (2) $15 \mathrm{~min}$; (3) $30 \mathrm{~min}$; (4) $60 \mathrm{~min}$ and (5) $90 \mathrm{~min}$.

In Figure 5, performance of the $\mathrm{TiO}_{2}$ thin-film photoanode in surfactant removal is evaluated as Percentage removal $(\%)$ of the surfactant and plotted in a timedependent scale as follows: $i$ ) absorbance monitored at $288 \mathrm{~nm}$; ii) $204 \mathrm{~nm}$. Percentage removal is the ratio of surfactant concentration variation at time $\left(\mathrm{C}_{\mathrm{t}}\right)$ to the initial dye concentration $\left(\mathrm{C}_{0}\right)$ in solution at $\mathrm{t}=0$. Concentration was determined by monitoring the absorbance of surfactant, from the UV-Visible absorption spectra as a function of time (shown in Figure 4). The percentage of all aromatic centre of the molecule reaches $100 \%$ after $60 \mathrm{~min}$ of photoelectrocatalytic oxidation, but removal at $285 \mathrm{~nm}$ is faster than at $224 \mathrm{~nm}$.

\section{pH influence on photoelectrocatalytic oxidation of surfactant Tamol®}

From a typical half-reaction occurring on the $\mathrm{TiO}_{2}$ photoanode (equations 1-3) the minority charge carriers

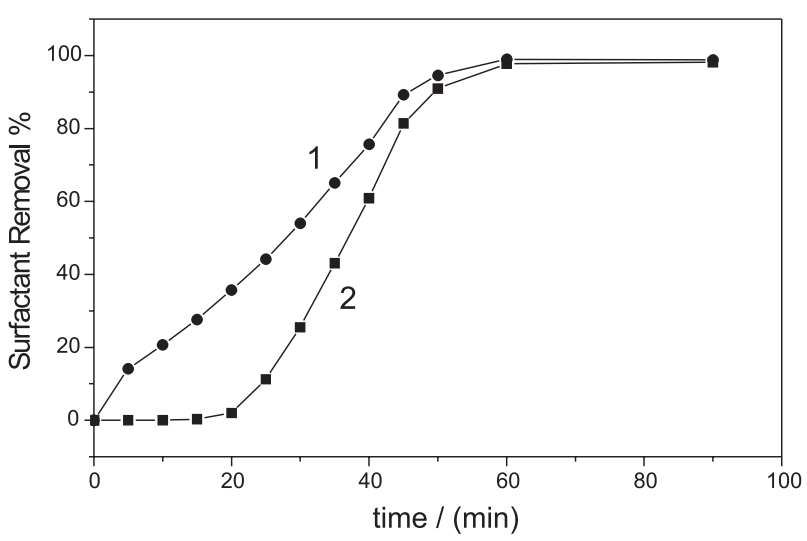

Figure 5. Graphs of percentage of surfactant removal during $90 \mathrm{~min}$ of photoelectrocatalytic oxidation on $\mathrm{Ti} / \mathrm{TiO}_{2}$ anodes under $\mathrm{E}=+1 \mathrm{~V}$ and UV irradiation. (1) $288 \mathrm{~nm}$ and (2) $224 \mathrm{~nm}$.

photogenerated upon illumination on the photoanode can oxidize the $\mathrm{H}_{2} \mathrm{O} / \mathrm{OH}^{-}$producing $\mathrm{OH}^{\bullet}$ radicals that adsorb on the photoelectrode surface with the release of $\mathrm{H}^{+}$ions to the solution. Thus, the reaction depends on the $\mathrm{pH}$ of the solution. The process can be resumed by the following equations: ${ }^{24}$

$$
\begin{aligned}
& \mathrm{TiO}_{2}+h \mathrm{v} \rightarrow \mathrm{TiO}_{2}-\mathrm{e}_{\mathrm{cb}}{ }^{-}+\mathrm{TiO}_{2}-\mathrm{h}_{\mathrm{vb}}{ }^{+} \\
& \mathrm{TiO}_{2}+\mathrm{h}_{\mathrm{vb}}{ }^{+}+\mathrm{H}_{2} \mathrm{O}_{\mathrm{s}} \rightarrow \mathrm{TiO}_{2}-\mathrm{OH}_{\mathrm{s}}{ }^{-}+\mathrm{H}^{+} \\
& \mathrm{TiO}_{2}-\mathrm{h}_{\mathrm{vb}}{ }^{+}+\mathrm{OH}_{\mathrm{s}}{ }^{-} \rightarrow \mathrm{TiO}_{2}-\mathrm{OH}_{\mathrm{s}}{ }^{+}
\end{aligned}
$$

As these reactions act to acidify the anode, hydrogen evolution $\left(2 \mathrm{H}_{2} \mathrm{O}+2 \mathrm{e}^{-} \rightarrow \mathrm{H}_{2}+2 \mathrm{OH}^{-}\right)$can generate a concomitant increase in the $\mathrm{pH}$ at the cathode. For this reason all the photoelectrocatalysis experiments were carried out maintaining the $\mathrm{pH}$ constant by correction of $\mathrm{pH}$ values.

The results comparing the surfactant degradation monitored at $285 \mathrm{~nm}$ and $224 \mathrm{~nm}$ during photoelectrocatalytic oxidation at $\mathrm{pH} 2,6$ and 12 presents marked difference as shown Curve I and II of Figure 6, respectively. The results illustrate that high surfactant degradation is more favorable at $\mathrm{pH}$ values maintained around $\mathrm{pH} 2$, but the degradation reaches $100 \%$ after $60 \mathrm{~min}$ of photoelectrocatalysis for both $\mathrm{pH} 2$ and 6 . On the other hand, by fixing the $\mathrm{pH}$ in 12 one stabilizes the $\mathrm{pH}$ and there is no need to add sodium hydroxide to correct the $\mathrm{pH}$ change during reaction, but the efficiency is markedly diminished.

The dependence of the initial degradation rate evaluated from slopes of the curves obtained for surfactant consumption $(\% \mathrm{~m} / \mathrm{v})$ monitored at $285 \mathrm{~nm}$ as function of time (s) at different $\mathrm{pH}$ is linearly decreased with the increase of photoelectrocatalytic oxidation concentration, following the equation: $\ln \mathrm{C} / \mathrm{C}_{\mathrm{o}}=-\mathrm{kt}$ (where, $\mathrm{C}=$ concentration 

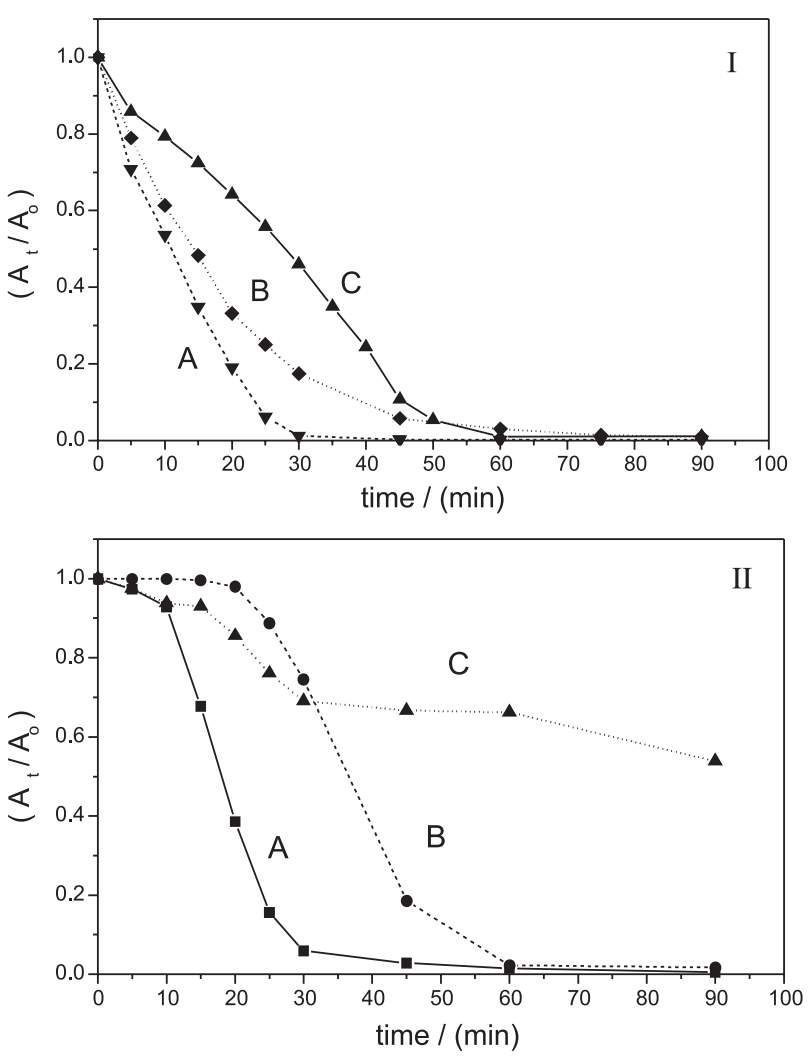

Figure 6. Effect of $\mathrm{pH}$ on the photoelectrocatalytic oxidation of surfactant $\mathrm{Tamol}^{\circledR}$ in $\mathrm{Na}_{2} \mathrm{SO}_{4} 0.1 \mathrm{~mol} \mathrm{~L}^{-1}$. Absorbance monitored at $285 \mathrm{~nm}$ (I) and $224 \mathrm{~nm}$ (II). (A) $\mathrm{pH}$ 2; (B) pH 6 and (C) pH 12.

of Tamol ${ }^{\circledR}$ at time t, $\mathrm{C}_{\mathrm{o}}=$ concentration of Tamol $^{\circledR}$ at time $=0$ and $\mathrm{k}=$ rate constant). This suggests that the initial rate for removal of surfactant follows a first order process with respect to Tamol ${ }^{\circledR}$. But, the respective values of rate constant obtained for surfactant degradation are $0.0703 \mathrm{~min}^{-1}$ for $\mathrm{pH} 2,0.0539 \mathrm{~min}^{-1}$ for $\mathrm{pH} 6$ and $0.0213 \mathrm{~min}^{-1}$ for $\mathrm{pH} 12$ $(\mathrm{n}=3)$, indicating that at alkaline conditions the process is always slower than acidic conditions.

Since the surface charge of the titanium dioxide electrode is influenced by solution $\mathrm{pH}$ and by dissolved species, previous studies ${ }^{24}$ measuring the zeta potential for suspended $\mathrm{TiO}_{2}$ particles as function of the $\mathrm{pH}$ of the suspension have indicated that isoelectric point for $\mathrm{TiO}_{2}$ was found to be 5.0. Taking into consideration that the surfactant $\mathrm{Tamol}^{\circledR}$ is an anionic compound the applied positive potential on the working electrode may increase its adsorption. At $\mathrm{pH}$ values higher than the isoelectric point, negative ions are repelled from the $\mathrm{TiO}_{2}$ surface. In addition, by increasing the solution $\mathrm{pH}$, concentration of $\mathrm{OH}^{-}$also increases, which is responsible for hydroxyl radical generation during the photocatalytic oxidation process. As a consequence, surfactant adsorption percentage could be diminished in conditions where the solution $\mathrm{pH}$ is higher than the isoelectric point $\mathrm{pH}$. In addition, carbonate formation could be occurring at $\mathrm{pH} 12$, which could decrease the efficiency of photoelectrocatalysis, since carbonate is well known hydroxyl radical scavenge.

HPLC analysis of the photoelectrocatalytic oxidation of surfactant Tamol $^{\circledR}$

In order to optimize the best chromatographic elution, $20 \mu \mathrm{L}$ of surfactant at concentration of $0.009 \%(\mathrm{~m} / \mathrm{v})$ was submitted to chromatographic separation testing acetonitrile/water at ratios of 80:20(v/v); 75:25 (v/v) and 65:35 (v/v) monitoring the diode array detection operating at $285 \mathrm{~nm}$. Chromatographic parameters as retention time, retention constant factor $\left(\mathrm{t}_{\mathrm{r}}\right)$ and resolution among peaks (r) were evaluated for the species under the experimental conditions proposed. The best condition was obtained for acetonitrile/water at ratios $80: 20 \mathrm{v} / \mathrm{v}$, which leads to an acceptable separation, good resolution between peaks $(\mathrm{r}>1.5)$ and analysis time around $10 \mathrm{~min}$. Figure 7, curve A exhibits a typical chromatogram obtained for surfactant. The chromatograms are characterized for a main peak at $3.5 \mathrm{~min}$ attributed to the surfactant peak, which increases linearly with Tamol ${ }^{\circledR}$ concentration from $0.00075 \%(\mathrm{~m} / \mathrm{v})$ to $0.07 \%(\mathrm{~m} / \mathrm{v})$ and two others small peaks at 2.5 and 2.1 min due impurities presented in the commercial sample of Tamol ${ }^{\circledR}$ donated by the Textile industry.

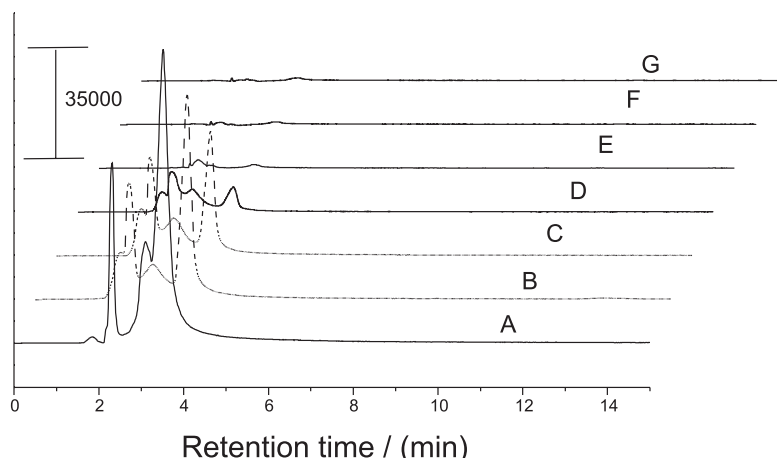

Figure 7. HPLC chromatograms with diode array detection obtained for $0.009 \%(\mathrm{~m} / \mathrm{v}) \mathrm{Tamol}^{\circledR}$ in $\mathrm{Na}_{2} \mathrm{SO}_{4} 0.1 \mathrm{~mol} \mathrm{~L}^{-1} \mathrm{pH} 2.0$ submitted to photoelectrocatalytic oxidation during (A) $0 \mathrm{~min}$; (B) $5 \mathrm{~min}$; (C) $10 \mathrm{~min}$; (D) $20 \mathrm{~min}$; (E) $30 \mathrm{~min}$ (F) $60 \mathrm{~min}$ and (G) $90 \mathrm{~min}$. Mobile phase: 80:20 acetonitrile/phosphate buffer $1 \times 10^{-3} \mathrm{~mol} \mathrm{~L}^{-1}, \mathrm{~T}=40^{\circ} \mathrm{C}$, flow $=1.0 \mathrm{~mL} \mathrm{~min}^{-1}(\lambda=285 \mathrm{~nm})$.

Figure 7 compares the effect of $90 \mathrm{~min}$ of photoelectrocatytic oxidation at $\mathrm{E}=+1.0 \mathrm{~V}$ from $0.009 \%(\mathrm{~m} / \mathrm{v})$ of $\mathrm{Tamol}^{\circledR}$ in $\mathrm{Na}_{2} \mathrm{SO}_{4} 0.1 \mathrm{~mol} \mathrm{~L}^{-1}$ on the chromatographic performance operating with diode array detector. The main peak is decreased markedly and is completely vanished after $30 \mathrm{~min}$ of photoelectrocatalysis. It is also observed that after 60 min of photoelectrocatalysis 
the baseline do not show any residues of surfactant or impurities. Also the chromatograms recorded for diode array operating from 200 to $800 \mathrm{~nm}$ do not exhibit any significant signal, suggesting that there is no measurable by-products generated after photoelectrocatalytic oxidation. The respective decreasing in peaks areas are shown in Figure 8. All the peak areas corresponding to the surfactant decreased after 90 min, suggesting that the photoelectrocatalytic technique could be a good treatment for anionic surfactant.

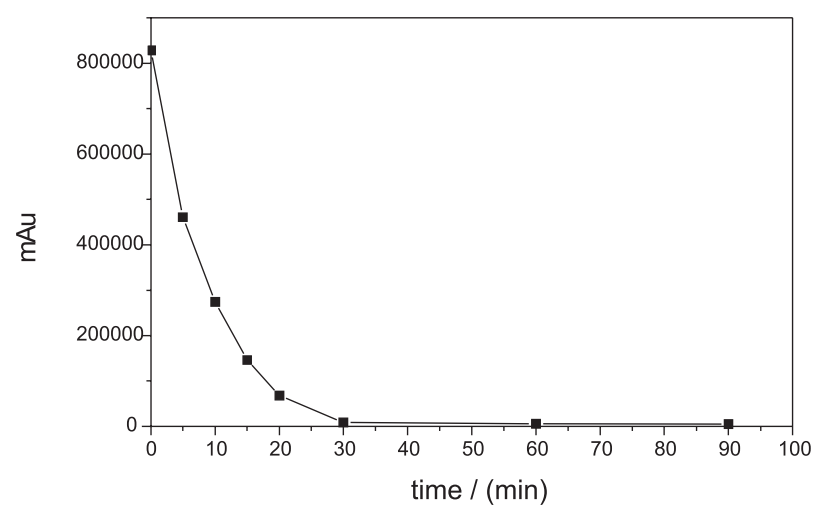

Figure 8. Graphs of media values of the area corresponding to the peak at 3.52 min obtained from HPLC-DAD chromatograms recorded for sample removed during photoeletrocatalytic oxidation of $0.009 \%(\mathrm{~m} / \mathrm{v})$ $\mathrm{Tamol}^{\circledR}$ in $\mathrm{Na}_{2} \mathrm{SO}_{4}$ pH 2.0 .

\section{TOC removal for surfactant Tamol ${ }^{\circledR}$}

From data above it is clear that the direct electrooxidation of surfactant $\mathrm{Tamol}^{\circledR}$ has a higher reaction rate on $\mathrm{TiO}_{2}$ thinfilm electrodes. The major practical interest in using the photoelectrocatalytic method is complete mineralization of surfactant. In this context, experiments have been conducted by monitoring the total organic carbon (TOC) removal under the same operational conditions used for surfactant removal.

TOC results obtained for aliquots of $0.009 \%(\mathrm{~m} / \mathrm{v})$ in $0.10 \mathrm{~mol} \mathrm{~L}^{-1}$ of $\mathrm{Na}_{2} \mathrm{SO}_{4}$ in different values of $\mathrm{pH}$ submitted to photoelectrocatalytic treatment during $90 \mathrm{~min}$ at potential of $+1.0 \mathrm{~V}$, under UV illumination are presented in Figure 9. The results obtained reaches maximum TOC removal values of $94.0 \%$ and $90.0 \%$ at $\mathrm{pH} 2.0$ and $\mathrm{pH}$ 6.0, respectively. The high TOC removal obtained at $\mathrm{pH} 2$ indicates that the mineralization of surfactant is very high, but on the other hand TOC removal is neglected at $\mathrm{pH}$ 12.0. Although the UV-Vis spectra pointed to excellent removal of the band at $285 \mathrm{~nm}$, TOC analysis indicates that by-products are formed during the photoelectrocatalytic oxidation and alkaline medium must be avoided.

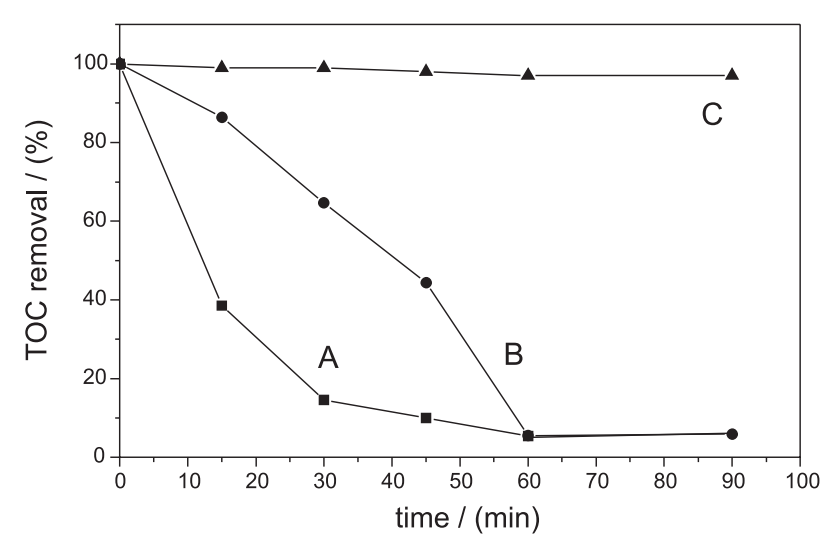

Figure 9. Effect of $\mathrm{pH}$ on the total organic carbon removal obtained during photoelectrocatalytic oxidation of $0.009 \%(\mathrm{~m} / \mathrm{v}) \mathrm{Tamol}^{\circledR}$ in $\mathrm{Na}_{2} \mathrm{SO}_{4}$ $0.1 \mathrm{~mol} \mathrm{~L}^{-1}$ at (A) $\mathrm{pH} 2$; (B) $\mathrm{pH} 6$ and (C) $\mathrm{pH} 12$.

\section{Photoelectrochemical pretreatment of the surfactant under leather dye preparation conditions}

In this part of the study, it was aimed to submit the anionic surfactant at an initial solution containing an azo dye assigned as acid red 151 commonly used in leather dyeing to mimic effluent from its preparation stage. For this experiment, a solution containing $0.003 \%(\mathrm{~m} / \mathrm{v})$ of acid red 151 dye $+0.009 \%(\mathrm{~m} / \mathrm{v})$ $\mathrm{Tamol}^{\circledast}$ in $0.1 \mathrm{~mol} \mathrm{~L}^{-1} \mathrm{Na}_{2} \mathrm{SO}_{4}$, pH 2.0 was submitted to photoelectrocatalytic oxidation during $90 \mathrm{~min}$. Concentrations of both acid red dye 151 and surfactant monitored at wavelength of $500 \mathrm{~nm}$ and $285 \mathrm{~nm}$, respectively decreases during treatment, are shown in Figure 10. It can be seen that the treatment leads to a decreasing of $98 \%$ of the original acid red dye after $90 \mathrm{~min}$. Curve B decreasing rate is slower when compared to the

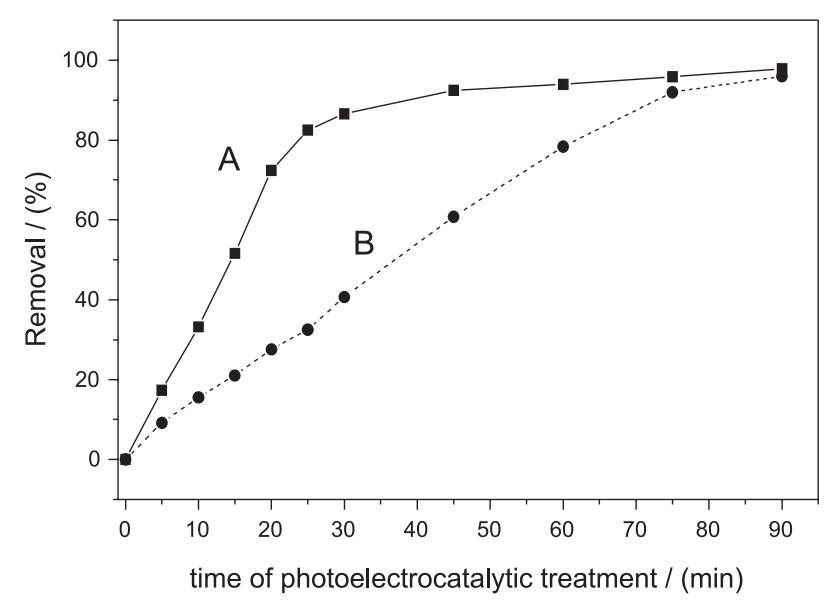

Figure 10. Percentage of removal of $0.003 \%(\mathrm{~m} / \mathrm{v})$ acid red dye 151 coloration monitored at $500 \mathrm{~nm}(\mathrm{~A})$ and $0.009 \%(\mathrm{~m} / \mathrm{v})$ surfactant agent $\mathrm{Tamol}^{\oplus}$ monitored at $285 \mathrm{~nm}$ (B) as a function of time of photoelectrocatalytic treatment on $\mathrm{TiO}_{2}$ thin-film electrode in $0.1 \mathrm{~mol} \mathrm{~L}^{-1} \mathrm{Na}_{2} \mathrm{SO}_{4}, \mathrm{pH} 2.0$. 


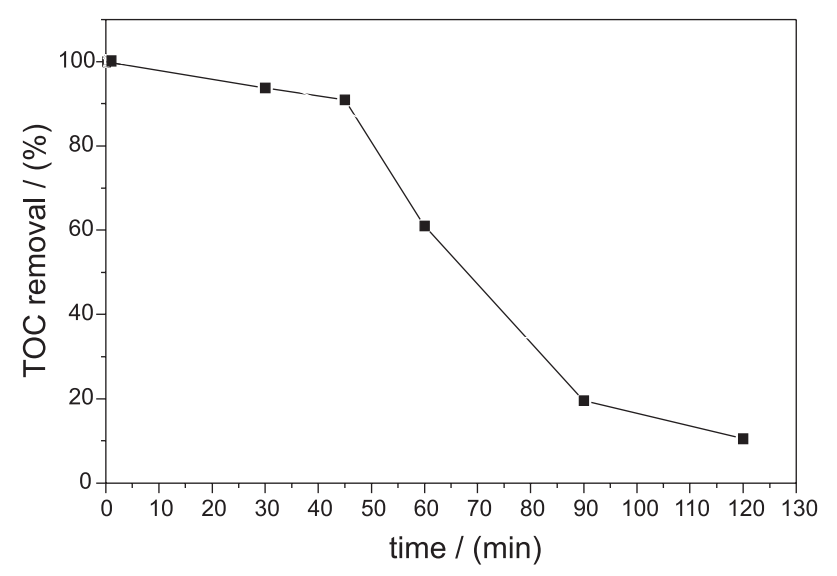

Figure 11. Percentage of dissolved total carbon organic removal of a solution containing $0.003 \%(\mathrm{~m} / \mathrm{v})$ of acid red 151 dye $+0.009 \%(\mathrm{~m} / \mathrm{v})$ of $\mathrm{Tamol}^{\circledR}$ in $0.1 \mathrm{~mol} \mathrm{~L}^{-1} \mathrm{Na}_{2} \mathrm{SO}_{4} \mathrm{pH} 2.0$ submitted to photoeletrocatalytic treatment on $\mathrm{TiO}_{2}$ thin-film electrode.

dye, but reaches $95 \%$ after 90 min of photoelectrocatalysis oxidation, demonstrating that the method could be explored for both dye and surfactant treatment. TOC abatement was also measured and the result is shown in Figure 11. As it can be seen, a maximum mineralization of $81.3 \%$ is reached after $90 \mathrm{~min}$ of photoelectrocatalytic oxidation. The results suggest that there is no total mineralization to $\mathrm{CO}_{2}$ of the dye containing surfactant solution but the photoelectrocatalytic results are very significant when compared to other processes described in the literature, ${ }^{4-12,19}$ and very close to those obtained for photoelectrochemical oxidation of solution containing only the surfactant.

The results indicate that $\mathrm{TiO}_{2}$ thin-film photoelectrodes prepared by sol-gel chemistry technique has proven to be a powerful, efficient alternative to usual approaches in degradation of both azo family acid dye and surfactant. This is importante, since most of the wastewater treatments for remediation of surfactant available until now are mainly on phase transfer techniques.

\section{Conclusion}

An alternative method for the degradation of surfactant widely used in leather industry is proposed. The best conditions for maximum photoelectrocatalytic oxidation were found to be at $\mathrm{pH} 2$ and at a potential of $+1 \mathrm{~V}$. In these conditions, it is possible to reach $100 \%$ of surfactant removal monitored by HPLC and UV spectra and 94\% of mineralization measured by TOC removal. The photoelectrocatalytic method describe here has shown that degradation rates are rapid compared to alternative oxidation process. Results were tested to treat anionic textile surfactant in the presence of acid dye used in the leather industry and the results were quite satisfactory. In conclusion, photoelectrochemical technique can potentially be applied to treat anionic textile surfactant at low concentration, since a dramatic reduction in both dye and surfactant amount can be obtained after short time of treatment.

\section{Acknowledgments}

The authors would like to thank financial support from Brazilian funding agencies FAPESP, process 04/07353-7, CAPES and CNPq.

\section{References}

1. Gustavson, K. H.; The Chemistry and Reactivity of Collagen, V.C.H. Publishers: New York, 1992, pp. 43-45, 136-140.

2. Alaton, I. A.; Erdinc, E.; Water Res. 2006, 40, 3409.

3. Schrank, S. G; Santos, J. N. R.; Souza, D. S.; Souza, E. S.; J. Photochem. Photobiol. A 2006, 186, 125.

4. Horikoshi, S.; Watanabe, N.; Onishi, H.; Hidaka, H.; Serpone, N.; Appl. Catal. B 2002, 37, 117.

5. Horváth, O.; Bodnár, E.; Hegyi, J.; Colloids Surf. A 2005, 265 , 135.

6. Zhang, T.; Oyama, T.; Horikoshi, S.; Zhao, J.; Serpone, N.; Hidaka, H.; Appl. Catal. B 2003, 42, 13.

7. Zhang, R.; Gao, L.; Zhang, Q.; Chemosphere 2004, 54, 405.

8. Hidaka, H.; Nohara, K.; Zhao, J.; Pelizzetti, E.; Serpone, N.; J. Photochem. Photobiol. A 1995, 91, 145.

9. Dai, Q.; Zhang, Z.; He, N.; Li, P.; Yuan, C.; Mater. Sci. Eng. C 1999, 8-9, 417.

10. Oyama, T.; Aoshima, A.; Horikoshi, S.; Hidaka, H.; Zhao, J.; Serpone, N.; Sol. Energy 2004, 77, 525.

11. Sánchez, L.; Romero, E.; Peña, A.; Chemosphere 2005, 59, 969.

12. Zhang, H.; Quan, X.; Chen, S.; Zhao, H.; Zhao, Y.; Appl. Surf. Sci. 2006, 252, 8598.

13. Önder, E.; Koparal, A. S.; Öğütveren, Ü. B.; Sep. Purif. Technol. 2007, 52, 527.

14. Lin, S. H.; Lin, C. M.; Leu, H. G.; Water Res. 1999, 33, 1735.

15. Arslan-Alaton, I.; Erdinc, E.; Water Res. 2006, 40, 3409.

16. Arslan-Alaton, I.; Alaton, I.; Ecotoxicol. Environ. Saf. 2007, $68,98$.

17. Hidaka, H.; Ajisaka, K.; Horikoshi, S.; Oyama, T.; Takeuchi, K.; Serpone, N.; J. Photochem. Photobiol. A 2001, 138, 185.

18. Fachini, A.; Joekes, I.; Clean Soil Air Wat. 2007, 35, 100.

19. Soares, E. T., Lansarin, M. A., Moro, C. C.; Braz. J. Chem. Eng. 2007, 24, 29.

20. Anderson, M. A.; Gieselmann, M. J.; Xu, Q. Y.; J. Membrane Sci. 1988, 39, 243.

21. Spanhel, L.; Anderson, M. A.; J. Am. Chem. Soc. 1991, 113, 2826. 
22. Candal, R. J.; Zeltner, W. A.; Anderson, M. A.; J. Adv. Oxid. Technol. 1998, 3, 270.

23. Candal, R. J.; Zeltner, W. A.; Anderson, M. A.; J. Environ. Eng-ASCE 1999, 125, 906.

24. Zanoni, M. V. B.; Sene, J. J.; Anderson, M. A.; J. Photoch. Phobio. A 2003, 157, 55.

25. Candal, R. J.; Zeltner W. A.; Anderson, M. A.; Environ. Sci. Technol. 2000, 34, 3443.

26. Xu, Q. Y.; Anderson, M. A.; J. Mater. Res. 1991, 6, 1073.

27. Kim, D. H.; Anderson, M. A.; Environ. Sci. Technol. 1994, 28 , 479.

28. Lin, W.Y., Wei C., Rajeshwar, K.; J. Electrochem. Soc. 1993 , $140,2477$.
29. Carneiro, A. P.; Osugi, M. E.; Sene, J.; Anderson, M. A.; Zanoni, M. V. B.; Electrochim. Acta 2004, 49, 3807.

30. Osugi, M. E.; Umbuzeiro, G. A.; De Castro, F. J. V.; Zanoni, M. V. B.; J. Hazard. Mater. 2006, 137, 871.

31. Osugi, M. E.; Umbuzeiro, G. A.; Anderson, M. A.; Zanoni, M. V. B.; Electrochim. Acta 2005, 50, 5261.

32. Carneiro, P. A.; Osugi, M. E.; Fugivara, C. S.; Boralle, N.; Furlan, M.; Zanoni, M. V. B.; Chemosphere 2005, 59, 431.

33. Carneiro, P. A.; Osugi, M. E.; Sene, J. J.; Anderson, M. A.; Zanoni, M. V. B.; Electrochim. Acta 2004, 49, 3807.

Received: August 30, 2007

Web Release Date: May 8, 2008

FAPESP helped in meeting the publication costs of this article. 